\title{
Assessment of Knowledge Levels of Nurses Working in Surgical Clinics About ERAS Protocol
}

\section{Cerrahi Kliniklerde Çalışan Hemşirelerin ERAS Protokolüne Yönelik Bilgi Düzeylerinin Incelenmesi}

\author{
Pınar Ongun ${ }^{1} \oplus$, Ezgi Seyhan $A^{2}{ }^{2} \odot$ \\ ${ }^{1}$ Balıkesir University, Faculty of Health Sciences, Department of Nursing, Balıkesir, Turkey \\ ${ }^{2}$ istanbul University-Cerrahpasa, Florence Nightingale Faculty of Nursing, Department of Surgical Nursing, Istanbul, Turkey
}

Received: 22.06.2020 / Accepted: 11.08.2020 / Published Online: 30.09.2020

Cite as: Ongun P, Ak ES. Assessment of knowledge levels of nurses working in surgical clinics about ERAS protocol. Med J Bakirkoy 2020;16(3):287-94.

\begin{abstract}
Objective: The aim of the study was to assess the knowledge levels of nurses working in surgical clinics about ERAS protocol.

Method: The study was carried out as a descriptive study. The sample of the study consisted of 127 surgical unit nurses who were not on leave or sick leave during the study period and who were willing to participate. A data collection form consisting of two sections and 47 questions developed by the researchers was used to collect the data. The necessary ethical and institutional approvals were obtained before the study.

Results: In the study $84.25 \%$ of the nurses stated that they did not know about the ERAS protocol, $88.97 \%$ indicated that the institution where they were working did not implement ERAS practices, $99.21 \%$ said that they did not follow any publication on the ERAS protocol, and $99.21 \%$ expressed that they did not receive any training on the ERAS protocol.

Conclusion: It was determined that most of the surgical nurses in the study did not know about the ERAS protocol and that ERAS protocol were not implemented in the clinic where they were working. In line with these results, we can recommend that surgical nurses follow the current developments and evidence-based guidelines on the ERAS protocol. Organization of trainings for the implementation of ERAS practices and ensuring the participation of nurses can help increase their knowledge levels in this regard.
\end{abstract}

Keywords: ERAS, nursing, information, enhanced recovery after surgery protocol

Öz

Amaç: Çalışmanın amacı cerrahi kliniklerde çalışan hemşirelerin ERAS protokolüne ilişkin bilgi düzeylerinin incelemektir. Yöntem: Çalışma tanımlayıcı olarak gerçekleştirildi. Araştırmanın örneklemini ise çalışmanın yapıldığı dönemde izinli/ raporlu olmayan ve araştırmaya katılma konusunda istekli olan 127 cerrahi birim hemşiresi oluşturdu. Verilerin toplanmasında araştırmacılar tarafından geliştirilen iki bölüm ve toplam 47 sorudan oluşan veri toplama formu kullanıldı. Çalışmaya başlamadan önce gerekli etik ve kurum izni alındı.

Bulgular: Çalışmada hemşirelerin \%84.25'i "ERAS protokolünü bilmediklerini, \%88,97'si çalıştıkları klinikte ERAS protokolü uygulamalarına yer verilmediğini, \%99,21'i ise "ERAS protokolüne yönelik herhangi bir yayını takip etmediğini, \%99,21'i ERAS protokolünü içeren herhangi bir eğitim almadığını belirtti.

Sonuç: Çalışmadaki cerrahi hemşirelerin çoğunluğunun ERAS protokolünü bilmedikleri ve çalıştıkları klinikte ERAS protokolü uygulamalarına yer verilmediği belirlendi Bu sonuçlar doğrultusunda cerrahi hemşirelerinin ERAS protokolüne yönelik güncel gelişmeleri ve kanıta dayalı rehberleri takip etmeleri, eras protokolü uygulamalarına yönelik eğitimlerin düzenlenmesi ve hemşirelerin katılımlarının sağlanması ile hemşirelerin bilgi düzeylerinin arttırılması önerilebilir.

Anahtar kelimeler: ERAS, hemşirelik, bilgi, cerrahi sonrası hızlandırılmış iyileşme protokolü 


\section{INTRODUCTION}

With the recent developments in surgical practices and anesthesia methods, in particular, there has been a significant increase in the number of patients who are undergoing surgery ${ }^{(1)}$. Due to this serious increase in patient population, the treatment and care protocols of hospitals are inadequate, so progress should be made with evidence-based practices instead of traditional approaches ${ }^{(1,2)}$. It is known that recovery after surgery can be accelerated and mortality due to surgery can be reduced with an up-todate approach on treatment and care in surgery and evidence-based practices. One of such evidencebased practices is the Enhanced Recovery After Surgery (ERAS) protocol, also known as the Fast Track Surgery (FTS) protocol, developed by the ERAS Society ${ }^{(3,4)}$. The ERAS protocol can be used for colorectal, gynecological and thoracic operations and other complex procedures ${ }^{(5)}$. The ERAS protocol requires a patient-centered, evidence-based and interdisciplinary approach to reduce patients' response to surgical stress, optimize their physiological functions and facilitate surgical recovery ${ }^{(6-11)}$. It is reported in the literature that ERAS has contributed to patient outcomes, reduced postoperative complications, accelerated recovery and supported early discharge ${ }^{(12-15)}$. Today, many evidence shows that the ERAS protocol reduces hospital stay by 2-3 days and morbidity and complication rates by $30-50 \%$. Correspondingly, it leads to a decrease in the cost of health services for both the institution and the patient ${ }^{(16-20)}$.

The components of the ERAS protocol include the preoperative, perioperative and postoperative periods. The preoperative period includes practices such as consultancy prior to admission, loading of liquid and carbohydrates, not prolonging fasting periods, not performing or selectively performing intestinal preparation, using antibiotic prophylaxis, thromboprophylaxis without premedication. The perioperative period includes practices such as using short-acting anesthetic agents, applying mid-thoracic epidural anesthesia/analgesia, avoiding drainage, salt and water loading and ensuring normothermia (heating the body, using heated intravenous fluids). The postoperative period includes practices such as applying mid-thoracic epidural anesthesia/analgesia, not using nasogastric tubes, preventing nausea and vomiting, avoiding salt and water loading, early removal of catheters, early initiation of oral feeding, using non-opioid oral analgesia, early mobilization, stimulating bowel movements and inspection of results and compliance with the protocol $(5,10,21)$.

However, the literature shows low rates of postoperative care in accordance with the ERAS protocol. McLeod et al. ${ }^{(22)}$ determined the obstacles for the implementation of ERAS to be the lack of workforce, hospital resources and participation and poor communication between team members. Successful implementation of ERAS depends on nurses to accept the use of this protocol and anesthesiologists and physicians to be in collaboration ${ }^{(6)}$. Considering the research on the implementation of ERAS, it is seen that most institutions focus on the perspective and effect of physicians' roles. However, taking into account that patient care is interdisciplinary in ERAS, nurses have a key role in overcoming ERAS implementation barriers and ensuring compliance with the protocol ${ }^{(11)}$. Understanding the role of nurses in the implementation of the ERAS protocol is important for future research. Although the global literature includes many studies on the ERAS protocol, there are only a limited number of studies on implementation involving the roles of nurses or its relationship with nursing ${ }^{233}$. There are also a limited number of reviews and researches by nurses on the ERAS protocol in Turkey ${ }^{(4,10,24-28)}$. In line with the information in the literature, the purpose of this study was to assess the knowledge levels of nurses working in surgical clinics about ERAS protocol and to contribute to the literature.

\section{MATERIAL and METHOD}

This study was carried out as a descriptive study between October 2018-March 2019 in the surgical units (orthopedics, plastic surgery, eye surgery, otolaryngology, urology, general surgery, neurosurgery and cardiovascular surgery) of one state, one city and one university hospital.

The target population of the study consisted of 360 nurses working in the surgical units (orthopedics, plastic surgery, eye surgery, otolaryngology, urology, general surgery, neurosurgery and cardiovascular 
surgery) of a State Hospital, a City Hospital and a University Hospital in the same city in Turkey. The sample of the study consisted of 127 surgical unit nurses working in the surgical units of a State Hospital, a City Hospital and a University Hospital in the same city hospital between October 2018-March 2019, who were not on leave and were willing to participate. The data were collected by the researchers in 10-15 minutes by face-to-face interviews with the nurses on their working days and at certain hours not interfering with their work after obtaining written and verbal permission from the participants.

A data collection form developed by researchers and consisting of two sections was used to collect data. After the form was created, it was revised in line with the expert opinions of 5 people on the ERAS protocol. The first section included 13 questions for demographic characteristics (age, marital status, gender, educational status, etc.), occupational data (total work years, work hours) and individual questions regarding ERAS. The second section consisted of 34 questions regarding the information on ERAS protocol ${ }^{(29-31)}$. The Statistical Package for the Social Sciences 25 (IBM SPSS) software was used for the statistical analyses. In data evaluation, descriptive statistical methods (mean, standard deviation, frequency, etc.) were used.

Before the study, ethical approval was received from the Ethics Committee of Balıkesir University (No: 20188/188), and institutional approvals were obtained from the state hospital and city hospital where the study was conducted. The nurses were informed that all information written on the forms would be kept by the researchers, that their answers would remain confidential and would only be used for scientific purposes. The nurses gave verbal and written permission regarding their willingness to participate in the study.

\section{RESULTS}

It was determined that $26.7 \%$ of the nurses participating in the study were aged between $37-42$ years, $59.05 \%$ had a bachelor's degree, $45.94 \%$ were in the profession for $\geq 16$ years, and $72.44 \%$ worked for 40-49 hours weekly (Table 1 ).

The statistical evaluation of the knowledge levels of the nurses regarding ERAS is given in Table 2. In the study $84.25 \%$ of the nurses stated that they did not

Table 1. Demographic characteristics of nurses working in surgical clinics ( $n=127)$.

\begin{tabular}{|c|c|c|c|}
\hline & & $\mathbf{n}$ & $\%$ \\
\hline \multirow[t]{5}{*}{ Age } & 19-24 age & 24 & 18.9 \\
\hline & $25-30$ age & 25 & 19.7 \\
\hline & 31-36 age & 17 & 13.4 \\
\hline & $37-42$ age & 34 & 26.7 \\
\hline & 42 age and above & 27 & 21.3 \\
\hline \multirow[t]{2}{*}{ Marital status } & Married & 89 & 70.07 \\
\hline & Single & 38 & 29.93 \\
\hline \multirow[t]{4}{*}{ Graduate program } & Vocational School of Health & 25 & 19.68 \\
\hline & Associate Degree & 20 & 15.74 \\
\hline & Bachelor's Degree & 75 & 59.05 \\
\hline & Postgraduate & 7 & 5.51 \\
\hline \multirow[t]{5}{*}{ Total years in the profession } & Less than 1 year & 5 & 3.94 \\
\hline & $1-5$ years & 27 & 21.26 \\
\hline & $6-10$ years & 26 & 20.47 \\
\hline & $11-15$ years & 14 & 11.02 \\
\hline & 16 years and above & 55 & 43.31 \\
\hline \multirow[t]{3}{*}{ Weekly work hours } & $40-49$ & 93 & 73.23 \\
\hline & $50-59$ & 23 & 18.11 \\
\hline & 60 hours and above & 11 & 8.66 \\
\hline \multirow[t]{3}{*}{ Hospital where they worked } & State hospital & 28 & 22.05 \\
\hline & City hospital & 60 & 47.24 \\
\hline & University hospital & 39 & 30.1 \\
\hline
\end{tabular}


Table 2. Knowledge on ERAS protocol $(n=127)$.

\begin{tabular}{|c|c|c|c|}
\hline & & $\mathbf{n}$ & $\%$ \\
\hline \multirow[t]{2}{*}{ Could you write down what you know about the ERAS protocol? } & I do not know & 107 & 84.25 \\
\hline & Other & 20 & 15.75 \\
\hline \multirow[t]{2}{*}{ Are there any sources where you follow the latest developments in the field of surgery? } & Yes & 7 & 5.51 \\
\hline & No & 120 & 94.49 \\
\hline \multirow[t]{2}{*}{ Are ERAS protocol practices implemented in your clinic? } & Yes & 14 & 11.02 \\
\hline & No & 113 & 88.98 \\
\hline \multirow[t]{2}{*}{ Are there any publications you follow for the ERAS protocol? } & Yes & 126 & 99.21 \\
\hline & No & 1 & 0.79 \\
\hline \multirow[t]{2}{*}{ Have you attended any training that includes the ERAS protocol? } & Yes & 126 & 99.21 \\
\hline & No & 1 & 0.79 \\
\hline \multirow[t]{3}{*}{ Do you think ERAS protocol practices are useful? } & Yes & 27 & 21.26 \\
\hline & No & 2 & 1.58 \\
\hline & I do not know & 98 & 77.16 \\
\hline
\end{tabular}

know about the ERAS protocol, $88.97 \%$ stated that the institution where they were working did not implement ERAS practices, 99.21\% indicated that they did not follow any publication on the ERAS protocol, 99.21\% reported that they did not receive any training on the ERAS protocol, and \%77.16 expressed that they did not know whether ERAS practices were useful.

The numbers and percentages of the responses to the questions for the preoperative, perioperative and postoperative parts of the ERAS protocol are given in Table 3. For the preoperative part, $95.27 \%$ of the surgical nurses stated that the item "Patient counseling and education should begin at the first visit and should continue throughout the surgical procedure" was "correct", and $74.80 \%$ stated that the item "clear fluids can be taken up to 2 hours before surgery" was "incorrect".

For the perioperative part, the item "Risk factors should be evaluated for nausea and vomiting after surgery" was found to be the most correct answer by $90.55 \%$, and the item "Short-acting anesthetics should be used" was the most incorrect answer by $19.68 \%$ of the participants. For the postoperative part, the item "Catheters should be removed as soon as possible" was found to be the most correct answer by $81.88 \%$, and "Oral feeding should be provided in the early postoperative period" was the most incorrect answer by $27.55 \%$ of the participants.

\section{DISCUSSION}

For enhanced recovery after surgery and the successful implementation of the ERAS protocol, it is important for nurses to have high awareness and knowledge about ERAS, in addition to all other healthcare team members. It is reported in the literature that there are gaps in the training of healthcare professionals in terms of ERAS protocols and the implementation of these protocols ${ }^{(32)}$. Conn et al. ${ }^{(33)}$ examined the experience of practitioners in successfully implementing postoperative recovery for elective colorectal surgery. In their qualitative study on 26 healthcare workers, they showed that most surgeons and anesthesiologists knew about the principles of ERAS, but most nurses did not know about the ERAS protocol. Similarly, Ince and Celebi (27) and Guzel and Yava ${ }^{(28)}$, Kirik ${ }^{(34)}$, Gustafsson et al. ${ }^{(35)}$ found that most nurses did not have sufficient knowledge about ERAS in perioperative care. We also determined that most of the nurses did not have information about the ERAS protocol in this study. This finding is similar to the literature, and we think that it may be due to the continuation of traditional practices rather than evidence-based practices such as ERAS in Turkey and in some other countries, and because nurses do not receive any training on ERAS and follow publications in this regard.

Successful implementation of the ERAS protocol is possible only through the collaboration of a team of surgeons, anesthesiologists and nurses (36). Herbert 
Table 3. Knowledge levels regarding ERAS protocol.

1. Patient counseling and education should begin at the patient's first visit and should continue throughout 95.27 the surgical procedure.

2. Patients should receive detailed education about the ERAS protocol with all team members.

$\begin{array}{lll}71.65 & 3.15 \quad 25.20\end{array}$

3. Smoking alcohol use and presence of anemia should be routinely investigated

4. The patient should stop smoking at least 4 weeks before the intervention.

$\begin{array}{lll}92.91 & 0 & 6.29\end{array}$

5. The patient should stop alcohol use at least 4 weeks before the intervention.

$62.99 \quad 7.09 \quad 29.92$

6. Blood glucose level should be kept at an optimum level.

$69.29 \quad 7.09 \quad 23.62$

7. Intestinal cleaning performed before surgery is effective in reducing infection rates.

$87.40 \quad 2.36 \quad 10.24$

8. Solid foods can be taken up to 6 hours before surgery.

$\begin{array}{lll}73.23 & 8.66 & 18.11\end{array}$

9. Heterogeneous liquids (juice) can be taken up to 4 hours before surgery.

$24.41 \quad 65.35 \quad 10.24$

10. Clear fluids can be taken up to 2 hours before surgery.

11. Administration of carbohydrate fluids until the midnight before surgery accelerates recovery in the pos- 11.81 toperative period.

12. The use of routinely applied long-acting sedatives should be avoided 12 hours before surgery.

13. Short-acting anxiolytics should be used before surgery.

14. Thromboembolism prophylaxis should be started the day before surgery.

$30.71 \quad 18.11 \quad 51.18$

15. Nutritional status should be evaluated, and nutritional support should be provided if NRS-2002/SGD-C score is above 3.

16. Short-acting anesthetics should be used.

17. Risk factors for nausea and vomiting after surgery should be evaluated.

18. Drainages, tubes and catheters should be used limitedly and only if necessary and should be removed as soon as possible.

19. Patients should be heated 10-20 minutes before surgery to ensure normothermia.

72.44

0

27.56

$41.73 \quad 19.69 \quad 38.58$

$90.55 \quad 1.58 \quad 7.87$

20. Antimicrobial prophylaxis should be done intravenously an hour before incision.

$81.89 \quad 2.36 \quad 15.75$

22. Advanced hemodynamic monitoring should be used for easy monitoring of fluid therapy and effective oxygen transport in the perioperative period.

23. Mid-thoracic epidural anesthesia/analgesia should be used.

24. Low-molecular-weight heparin should be used for postoperative thromboembolism prophylaxis.

25. Antiemetic prophylaxis should be performed to reduce nausea and vomiting after surgery.

26. Catheters should be removed as soon as possible.

27. High energy fluids after surgery should contain protein/carbohydrate.

2.36

15.75

28. Balanced crystalloid solutions should be used instead of $0.9 \%$ sodium chloride to prevent hyperchloremic acidosis.

30. Controlled insulin therapy and regular blood glucose monitoring should be performed to prevent the development of hypoglycemia in patients with severe hyperglycemia.

31. Opioid use should be reduced after surgery.

32. A multimodal pain relief method should be used to control pain.

33. Oral feeding should be provided in the early postoperative period.

34. Patients should be kept out of bed for 2 hours on the day of surgery and 6 hours a day until discharge.

$51.18 \quad 16.54 \quad 32.28$

$\begin{array}{ll}5.51 & 25.20\end{array}$

$3.93 \quad 18.90$

$8.66 \quad 29.13$

$35.43 \quad 14.96 \quad 49.61$

$56.69 \quad 7.09 \quad 36.22$

$\begin{array}{lll}74.80 & 3.94 & 21.26\end{array}$

$81.89 \quad 0.79 \quad 17.32$

$\begin{array}{lll}59.06 & 10.24 & 30.71\end{array}$

$\begin{array}{lll}38.58 & 8.66 \quad 52.76\end{array}$

$30.71 \quad 26.77 \quad 42.52$

$\begin{array}{lll}74.02 & 4.72 & 21.26\end{array}$

$\begin{array}{lll}57.48 & 4.72 & 37.80\end{array}$

$\begin{array}{lll}57.48 & 1.58 & 40.94\end{array}$

$\begin{array}{lll}53.54 & 27.56 \quad 18.90\end{array}$

$\begin{array}{lll}62.22 & 13.37 & 24.41\end{array}$

et al. ${ }^{(37)}$ stated that ERAS is a strong evidence-based practice, but it has a slow transition to practice in clinics. Ament et al. ${ }^{(38)}$ stated that the communication, institutional culture and structural features of clinics (circulation of employees) are common issues related to the applicability and sustainability of the ERAS protocol. Most of the nurses participating in this study stated that ERAS practices were not included in the clinic where they worked. This finding shows that the institutional culture and structural features of the clinics may have been effective in the lack of implementation of ERAS in the clinics where the nurses worked.

The ERAS protocol covers both preoperative, perio- perative and postoperative periods. This protocol includes practices such as preoperative patient education and counseling, prevention of prolonged hunger due to surgery through nutrition, standardized analgesic and anesthetic regimens and early mobilization $^{(23,39-41)}$.

Educating patients before the surgery about issues such as the surgical team, possible complications and their management, pain management, etc. is the most important component of the ERAS protocol ${ }^{(23,42)}$. Inci and Celebi ${ }^{(27)}$ found that the knowledge of nurses on preoperative training and counseling was compatible with ERAS. Similarly, in this study, the fact that the nurses knew that patients should be 
educated in the preoperative period is compatible with the ERAS protocol.

The 2011-2017 guidelines of the American Society of Anesthesiologists (ASA) states that it is sufficient to stop the consumption of solid foods six hours before the operation and that of clear liquids two hours before the operation ${ }^{(43)}$. Patients undergoing surgery should be given $800 \mathrm{ml}$ of liquid food rich in carbohydrates until the midnight before surgery and $400 \mathrm{ml}$ 2-3 hours before surgery. This practice has been shown to improve postoperative well-being, reduce insulin resistance and significantly shorten hospital stay ${ }^{(44)}$. In the study of Inci and Celebi ${ }^{(27)}$, the knowledge levels of nurses regarding fasting times were not found to be compatible with the ERAS protocol. In the study of Kankilic and Tuna ${ }^{(45)}$, it was found that only $4.2 \%$ of healthcare professionals performed practices in line with the fasting recommendations of the ERAS protocol. Similarly, in this study, the knowledge levels of nurses regarding fasting times before surgery were not found to be compatible with the ERAS protocol. This result may be related to the continuation of the traditional attitudes of nurses working in surgical clinics regarding fasting times and their lack of sufficient knowledge in this regard.

Postoperative nausea-vomiting should be prevented, because it can restrict the oral feeding of patients in the early period. For this purpose, the use of agents that can induce vomiting should be avoided during the surgery, and combined antiemetic agents should be used (highly evidenced, strongly recommended) $(35,44)$. In this study, the knowledge levels and practices of nurses regarding nausea and vomiting were compatible with the ERAS protocols. This may suggest that nurses are conscious about risk factors in preventing nausea and vomiting after surgery and that antiemetic drugs are routinely applied during operations. A wide variety of agents are used to reduce preoperative anxiety. In practices similar with the ERAS protocol, long-acting premedication agents should be avoided ${ }^{(46)}$. In this study, it was seen that nurses had limited knowledge on the use of shortacting anesthetics.

It is recommended that urinary catheters should be removed in the early period due to their disadvantages such as urinary infection and restriction of mobi- lization ${ }^{(1,35)}$. In the current study, we observed that the practices of nurses regarding the removal of catheters were in accordance with the ERAS protocol. This may be due to the fact that the early removal of catheters is a routine practice performed in the clinics. The transition to oral feeding in the early postoperative period reduces both hospital stay and infection risk. However, early oral feeding may increase the risk of vomiting and may lead to problems such as delay in mobilization, pulmonary problems and bloating when a multimodal treatment is not applied (47). In the study of Inci and Celebi (27), it was observed that nurses had low levels of knowledge regarding transition to oral feeding in the postoperative period. Similarly, in this study, we observed that the practices of nurses regarding transition to oral feeding in the postoperative period were in line with the ERAS protocols.

Limitations: The study was limited to State Hospital, City Hospital and University Hospital in the same city.

\section{CONCLUSIONS}

In conclusion, we determined that most of the surgical nurses in the study did not know about the ERAS protocol, that ERAS practices were not included in the clinics where they were working, that they did not follow any publications regarding the ERAS protocol, that they received no training including the ERAS protocol and that they did not know whether ERAS practices were useful. It was seen that the nurses had limited knowledge levels regarding the intake of clear fluids up to 2 hours before surgery, the preference of using short-acting anesthetics and the transition to oral feeding in the early postoperative period. In line with these results, we can recommend that surgical nurses follow the current developments and evidencebased guidelines on the ERAS protocol. Organization of trainings for the implementation of ERAS practices and ensuring the participation of nurses can help increase their knowledge levels in this regard. Considering the literature, it is seen that there are limited international and national publications on the topic. Thus, further studies with larger sample groups and different study types can be planned.

Ethics Committee Approval: Ethical approval was received from the Ethics Committee of Balıkesir 
University (No: 20188/188), and institutional approvals were obtained from the state hospital and city hospital where the study was conducted.

Conflict of interests: Authors have no conflict of interest.

\section{Funding: There are no financial supports.}

Informed Consent: Informed consent was obtained from all individual participants included in the study.

\section{REFERENCES}

1. Demirhan I, PInar G. Enhanced recovery after surgery and nursing practices enhanced recovery and nursing. Yıldırım Beyazıt Üniversitesi Sağlık Bilimleri Fakültesi Hemşirelik E-Dergisi. 2014;(2)1:43-53. Available from: http://hdergi.ybu. edu.tr/index.php/e-dergi/article/view/62

2. Batdorf NJ, Lemaine V, Lovely JK, Ballman KV, Goede WJ., Martinez-Jorge J, et al. Enhanced recovery after surgery in microvascular breast reconstruction. J Plast Reconstr Aesthet Surg. 2015;68(3):395-402. https://doi.org/10.1016/j.bjps.2014.11.014

3. Abdikarim I, Cao XY, Li SZ, Zhao YQ, Taupyk, Y, Wang Q. Enhanced recovery after surgery with laparoscopic radical gastrectomy for stomach carcinomas. World J Gastroenterol. 2015;21(47):13339-44. https://doi.org/10.3748/wjg.v21.i47.13339

4. Cilingir D, Candas B. Enhanced recovery after surgery protocol and nurse's role. Journal of Anatolia Nursing and Health Sciences. 2017;20(2):137-43. Available from: https://dergipark.org.tr/tr/download/article-file/348666

5. Persico M, Miller D, Way C, Williamson M, O'Keefe K, Strnatko $D$, et al. Implementation of enhanced recovery after surgery in a community hospital: an evidence-based approach. J Perianesth Nurs. 2019;34(1):188-197.

https://doi.org/10.1016/j.jopan.2018.02.005

6. Hübner M, Addor V, Slieker J, Griesser AC, Lécureux E, Blanc $C$, et al. The impact of an enhanced recovery pathway on nursing workload: a retrospective cohort study. Int J Surg. 2015;24(Pt A):45-50.

https://doi.org/10.1016/j.ijsu.2015.10.025

7. Feldheiser A, Aziz O, Baldini G, Cox BPBW, Fearon $\mathrm{K} \mathrm{CH}$, Feldman LS, et al. Enhanced recovery after surgery (ERAS) for gastrointestinal surgery, part 2: consensus statement for anaesthesia practice. Acta Anaesthesiol Scand. 2016;60(3):289334.

https://doi.org/10.1111/aas.12651

8. Bray MS, Appel AL, Kallies KJ, Borgert AJ, Zinnel BA, Shapiro $\mathrm{SB}$. Implementation of an enhanced recovery after surgery program for colorectal surgery at a community teaching hospital. WMJ. 2017;116(1):22-6. Available from: https://wmjonline.org/wp-content/uploads/2017/116/1/22.pdf

9. Watson DJ. The role of the nurse coordinator in the enhanced recovery after surgery program. Nursing. 2017;47(9):13-7. https://doi.org/10.1097/01.NURSE.0000522018.00182.c7

10. Aksoy A, Vefikulucay Yılmaz D. A new approach to evidence based practices in gynecological surgery: ERAS protocol and nursing. Turkiye Klinikleri J Nurs Sci. 2018;10(1):49-58. https://doi.org/10.5336/nurses.2017-56268

11. Brown D, Xhaja A. (2018). Nursing perspectives on enhanced recovery after surgery. Surg Clin North Am. 2018;98(6):121121. https://doi.org/10.1016/j.suc.2018.07.008

12. Adamina M, Kehlet $H$, Tomlinson GA, Senagore AJ, Delaney CP. Enhanced recovery pathways optimize health outcomes and resource utilization: a meta-analysis of randomized cont- rolled trials in colorectal surgery. Surgery. 2011;149(6):83040. https://doi.org/10.1016/j.surg.2010.11.003

13. Hughes MJ, McNally S, Wigmore SJ. Enhanced recovery following liver surgery: a systematic review and meta-analysis. HPB (Oxford). 2014;16(8):699-706. https://doi.org/10.1111/hpb.12245

14. Miller TE, Thacker JK, White WD, Mantyh C, Migaly J, Jin J, et al. Reduced length of hospital stay in colorectal surgery after implementation of an enhanced recovery protocol. Anesth Analg. 2014;118(5):1052-61. https://doi.org/10.1213/ANE.0000000000000206

15. Scott MJ, Miller TE. Pathophysiology of major surgery and the role of enhanced recovery pathways and the anesthesiologist to improve outcomes. Anesthesiol Clin. 2015;33(1):79-91. https://doi.org/10.1016/j.anclin.2014.11.006

16. Archibald LH, Ott MJ, Gale CM, Zhang J, Peters MS, Stroud GK. Enhanced recovery after colon surgery in a community hospital system. Dis Colon Rectum. 2011;54(7):840-5. https://doi.org/10.1007/DCR.0b013e31821645bd

17. Melnyk M, Casey RG, Black P, Koupparis AJ. Enhanced recovery after surgery (ERAS) protocols: time to change practice? Can Urol Assoc J. 2011;5(5):342-8. https://doi.org/10.5489/cuaj.11002

18. Chandrakantan A, Gan TJ. Demonstrating value: a case study of enhanced recovery. Anesthesiol Clin. 2015;33(4):629-50. https://doi.org/10.1016/j.anclin.2015.07.004

19. Stowers MD, Lemanu DP, Hill AG. Health economics in enhanced recovery after surgery programs. Can J Anaesth. 2015;62(2):219-30. https://doi.org/10.1007/s12630-014-0272-0

20. Thiele RH, Rea KM, Turrentine FE, Friel CM, Hassinger TE, Goudreau BJ, et al. Standardization of care: impact of an enhanced recovery protocol on length of stay, complications, and direct costs after colorectal surgery. J Am Coll Surg. 2015;220(4):430-43. https://doi.org/10.1016/j.jamcollsurg.2014.12.042

21. Bernard H, Foss, M. Patient experiences of enhanced recovery after surgery (ERAS). Br J Nurs. 2014;23(2):100-6. https://doi.org/10.12968/bjon.2014.23.2.100

22. McLeod RS, Aarts MA, Chung F, Eskicioglu C, Forbes SS, Conn LG, et al. Development of an enhanced recovery after surgery guideline and implementation strategy based on the knowledge-to-action cycle. Ann Surg. 2015;262(6):1016-25. https://doi.org/10.1097/SLA.0000000000001067

23. Mendes DIA, Ferrito CRDAC, Gonçalves MIR. Nursing ınterventions in the enhanced recovery after surgery ${ }^{\circledR}$ : scoping review. Rev Bras Enferm. 2018;71(suppl 6):2824-32. https://doi.org/10.1590/0034-7167-2018-0436

24. Kabatas MS, Ozbayır T. Enhanced recovery after surgery (ERAS) protocols after colorectal surgery: a systematic review. Gümüşhane University Journal of Health Sciences. 2016;5(3):120-32. Available from: https://dergipark.org.tr/tr/ download/article-file/220051

25. Unlü $\mathrm{H}$. Nursing care in elderly patients who were total hip or knee arthroplasty with rapid recovery protocol. Turkiye Klinikleri J Surg Nurs-Special Topics. 2017;3(2):143-50. Available from: https://www.turkiyeklinikleri.com/article/en-hizliiyilesme-protokolu-ile-total-kalca-veya-diz-artroplastisiyapilan-yasli-hastalarda-hemsirelik-bakimi-78855.html

26. Tuna PT, Kursun S. ERAS and nursing care for colon surgery. Dokuz Eylül Üniversitesi Hemşirelik Fakültesi Elektronik Dergisi. 2018;11(2):180-88. Available from: https://dergipark. org.tr/tr/download/article-file/752812

27. Celebi E, llce A. Determination of knowledge levels of nurses working in surgical clinics on ERAS protocols. In: 3. International, 11. National Turkish Surgical and Operating Room Nursing Congress Book. 2019. p. 392-400.

28. Guzel N, Yava A. The determination of knowledge and attitudes on enhanced recovery after surgery protocol of the nurses who working on surgical units. Journal of Zeugma Health 
Sciences. 2019;1(1):15-23. Available from: https://sbf.hku. edu.tr/wp-content/uploads/2020/01/Cerrahi-kliniklerinde\%C3\%A7al\%C4\%B1\%C5\%9Fan-hem\%C5\%9Firelerin-ERASenhanced-recovery-after-surgery-protokol\%C3\%BCneili\%C5\%9Fkin-bilgi-ve-tutumlar\%C4\%B1n\%C4\%B1nbelirlenmesi.pdf

29. Lassen K, Coolsen MM, Slim K, Carli F, de Aguilar-Nascimento JE, Schäfer M, et al. Guidelines for perioperative care for pancreaticoduodenectomy: enhanced recovery after surgery (ERAS $\left.{ }^{\circledR}\right)$ Society recommendations. World J Surg. 2013; 37(2):240-58.

https://doi.org/10.1007/s00268-012-1771-1

30. Elias KM. Understanding enhanced recovery after surgery guidelines: an introductory approach. J Laparoendosc Adv Surg Tech A. 2017;27(9):871-5.

https://doi.org/10.1089/lap.2017.0342

31. American Association of Nurse Anesthetists. Enhanced recovery after surgery. Available from: https://www.aana.com/ practice/clinical-practice-resources/enhanced-recoveryafter-surgery (cited 2019 April 22)

32. Austin J. The effect of an education plan on nursing intervention compliance with inpatient post-operative colorectal surgical patients using enhanced recovery after surgery (ERAS) protocols [doctoral dissertation]. USA: University of Kentucky, College of Nursing; 2019.

33. Conn LG, McKenzie M, Pearsall EA, McLeod RS. Successful implementation of an enhanced recovery after surgery programme for elective colorectal surgery: a process evaluation of champions' experiences. Implement Sci. 2015;10:99. https://doi.org/10.1186/s13012-015-0289-y

34. Kırık MS. Kolorektal ameliyatlarda klinik alanda ameliyat öncesi sırası ve sonrası uygulamaların ERAS protokolüne uygunluğunun karşılaştırılması [master's thesis]. Gaziantep: Sanko Üniversitesi, Sağlık Bilimleri Enstitüsü; 2018.

35. Gustafsson UO, Scott MJ, Hubner M, Nygren J, Demartines N Francis $\mathrm{N}$, et al. Guidelines for perioperative care in elective colorectal surgery: enhanced recovery after surgery (ERAS) society recommendations. World J Surg. 2019;43(3):659-95. https://doi.org/10.1007/s00268-018-4844-y

36. Bozkırlı BO, Gündogdu RH, Ersoy PE, Akbaba S, Temel H, Sayın T. ERAS protokolü kolorektal cerrahi sonuçlarımızı etkiledi mi?. Turkish Journal of Surgery. 2012;28(3):149-52. https://doi.org/10.5152/UCD.2012.05

37. Herbert G, Sutton E, Burden S, Lewis S, Thomas S, Ness A, et al. Healthcare professionals' views of the enhanced recovery after surgery programme: a qualitative investigation. BMC Health Serv Res. 2017;17(1):617. https://doi.org/10.1186/s12913-017-2547-y

38. Ament SM, Gilliseen F, Moser A, Maessen JM, Dirksen CD, von
Meyenfeldt MF, et al. Factors associated with sustainability of 2 quality improvement programs after achieving early implementation success. A qualitative case study. J Eval Clin Pract. 2017;23(6):1135-43. https://doi.org/10.1111/jep.12735

39. Nelson G, Altman A, Nick A, Meyer L, Ramirez PT, Achtari C, et al. Guidelines for preand intraoperative care in gynecologic/ oncology surgery: enhanced recovery after surgery (ERAS ${ }^{\circledR}$ ) society recommendations. Gynecol Oncol. 2016;140(2):31322 https://doi.org/10.1016/j.ygyno.2015.11.015

40. Gan TJ, Scott M, Thacker, J, Hedrick T, Thiele RH, Miller TE. American society for enhanced recovery: Advancing enhanced recovery and perioperative medicine. Anesth Analg. 2018;126(6):1870-3. https://doi.org/10.1213/ANE.0000000000002925

41. Dort JC, Farwell DG, Findlay M, Huber GF, Kerr, P, Shea-Budgell $M A$, et al. Optimal perioperative care in major head and neck cancer surgery with free flap reconstruction: a consensus review and recommendations from the enhanced recovery after surgery society. JAMA Otolaryngol Head Neck Surg. 2017;143(3):292-303. https://doi.org/10.1001/jamaoto.2016.2981

42. Tezber K, Aviles C, Eller M, Cochran A, lannitti D, Vrochides D, et al. Implementing enhanced recovery after surgery (ERAS) program on a specialty nursing unit. J Nurs Adm. 2018;48(6):303-9. https://doi.org/10.1097/NNA.0000000000000619

43. Gok F, Yavuz Van Giersbergen, M. Preoperative fasting: a systematic review. Pamukkale Medical Journal. 2018;11(2): 183-94. https://doi.org/10.5505/ptd.2017.50490

44. ERAS Türkiye Derneği. Available at: http://eras.org.tr/page. (cited 2020 April 5).

45. Kankılıc R, Tuna A. An investigation of preoperative and postoperative nutrition, pain and early mobilisation practices in TUR-P surgery in relation to the ERAS protocol. KSU Medical Journal. 2019;14(2):69-74. https://doi.org/10.17517/ksutfd.484635

46. Umari M, Falini S, Segat M, Zuliani M, Crisman M, Comuzzi L, et al. Anesthesia and fast-track in videoassisted thoracic surgery (VATS): from evidence to practice. J Thorac Dis. 2018;10(Suppl 4):S542-54 https://doi.org/10.21037/jtd.2017.12.83

47. Gundogdu RH. Cerrahi iyileşmenin hızlandırılması için modern teknikler. In: Eti Aslan F, editor. Cerrahi bakım vaka analizleri ile birlikte. Ankara: Akademisyen Tip Kitabevi; 2016. p. 45570. 